\title{
The Management Of The Education Operational Grant And Its Effects On School Development
}

\author{
Rismita $^{1^{*}}$, Maya Syafriana Effendi ${ }^{2}$, Fetrimen ${ }^{3}$, Ihsana EI Khuluqo ${ }^{4}$ \\ 1, 3, 4 Educational Administration, Universitas Muhammadiyah PROF. DR. HAMKA (UHAMKA), Jakarta, Indonesia \\ ${ }^{2}$ Management, Persada Indonesia University YAI, Jakarta, Indonesia \\ e-mail: rismita@uhamka.ac.id, mayasyafriana@gmail.com, fetrimen@uhamka.ac.id, \\ insana_khluqo@uhamka.ac.id
}

\begin{abstract}
The problem that has occurred in schools is in managing education operational aid funds in the current year is not in accordance with the recording of recapitulation of data for students who receive funds resulting in each area in use there is a difference or the remaining funds and less effective in managing expenditure per student by comparing school districts which is based on the previous year's budget that has already happened. This study aims to analyze the management of school fund management towards school development. The research method used is descriptive qualitative research by explaining the function of management. Data collection techniques in this study were interviews with the principal, deputy headmaster of the curriculum, the head of school administration, observation, and documents relating to the accountability of funds. The results of the study are grouping funds according to school programs, there is no waste of funds based on the percentage of funding funding per quarter. The Principal builds a system of monitoring the use of funds in an accountable and accurate manner in achieving the vision and mission of the school
\end{abstract}

Keywords: Fund Management; Education Operational Grant; School Development

\section{Introduction}

School development towards progress and quality requires change and transformation that has an impact on achieving long-term school goals that each country in maintaining high growth rates for a long period of time makes substantial efforts in educating its citizens and enhancing human resource development (World Bank, 2008). The success of school development is the role of school leadership in taking responsibility for school management so that it can improve learning outcomes and the application of national curriculum standards (Uljens \& Ylimaki, 2017), and lead to the emotional intelligence literature that is useful for meaningful management implications for schools and education systems (Mohamad \& Jais, 2016), as well as increasing competencies such as the ability to develop others in facing challenges in the world of education (Ishak et al., 2010). The principal's ability to solve a problem in order to effectively achieve policy goals by applying conceptual abilities as individuals in school and systemic institutions (World Bank, 2004).

Achievement of educational policy objectives in schools requires assistance from the government in the form of educational operational grant that is useful to assist students in attending education in schools. This grant is the source of education resources as stated in the article 1 verse 23 of the Act of the Republic of Indonesia no 20/2003 on the National Education System that the education resources mean anything utilized in the provision of education, including educational personnel, communities, fund, facilities and equipment. Because education may improve one's life quality and give social benefits for individuals and communities and is a dynamic process with the education system in dealing with social problems that are applied to the educational process (Haynes et al., 2015). Social problems include easing parents' burden on their children's education for those who cannot afford education funding and reducing school dropout rates.

\footnotetext{
* Corresponding author.

Received 2 October 2019; Accepted 28 June 2020; Available online 20 June 2020

(C) 2020 JPI. All Rights Reserved
}

Jurnal Pendidikan Indonesia (JPI) | 328 
Overcoming these social problems, schools that receive educational operational grant should manage finances according to the functions and roles of school financing related to the education economy and various activities related to school fund management, based on financial management principles (flexibility, effectiveness, efficiency, accountability, and transparency) contained in "Regulation of the Minister of Education and Culture of the Republic of Indonesia Number 8 of 2020 concerning Technical Guidelines for Regular School Operational Grant" and School Income and Expenditures Budget Plans (RAPBS) for one school academic year that is the responsibility of the school principal and all parties involved in fund management, because fund management that is not in accordance with the principle will be a long-term problem so that public services will be of low quality and uneven in education due to weak accountability of providers to supervisors and users. education hopes, and educational operational grant funds are used to empowering poor people and the disenfranchised - the people" at the fringes "- and giving them a real stake in society is the key to building the stronger institutions required for longer term sustainable development (Weltbank, 2003), because it will significantly influence professional actions in protecting the intellectual abilities of students to be valuable (Howieson, 2003), towards achieving long-term development in the education process that will affect school development and the quality of schools that are related to investment in resources - resources to obtain educational benefits in the future. Related research states that, education is the surest path to financial security, but he argues that the return to education is not evenly recognized in all disciplines (Weber, 2014).

School financial security is a form of responsibility for educational operational grant by implying a management process that is planning, organizing, implementing, and monitoring. The management implications are applied based on the provisions, where the government provides Educational Operational Grant (BOP) to schools based on the number of students in the school. Referring to the provision that assistance is given based on the number of students, that Central Jakarta 30 High Schools in managing BOP funds in the current year are not in accordance with the recording of data recapitulation for students who receive BOP funds resulting in every area in use there is a difference or the remaining funds so these funds must be returned. This is a series of basic and sequential problems that require more complex accountability. In fact, good fund management is related to the quality of schools achieved, as stated by Bruns that, quality could be evaluated by ensuring that human resources follow the predefined steps. But education services are complicated. At the point of explanation the interaction of teachers with their students the service provided is highly discretionary, variable, and transaction-intensive (Bruns et al., 2011).

Overcoming the above problem, it is better for schools to isolate exogenous variations in school expenditures per student by comparing school districts with reference to the budget that had occurred in the previous year (Lee \& Polachek, 2018), which resulted in every decision on the issue of school financing will affect how resources are obtained and allocated. Government responsibility in financing education needs to be seen from the factors of the need and availability of education, the responsibilities of parents in schooling versus social benefits at large, the influence of political and economic factors on the education sector (Fattah, 2008). Schools, in this case do not use questionnaire surveys in data collection of students who receive education operational grant funds and the management board of management is not in accordance with the task, however, that the management board is efficient in managing human resources in related activities (Manu et al., 2019).

Based on the Educational Operational Grant fund management phenomenon above, that Educational Operational Grant funds need to be managed with a financial management function based on technical guidelines for the use and accountability of funds so that the funding assistance provided by the government to schools is in accordance with the needs of the schools that have an influence on school development. Indicators of good management, namely planning, utilization, and reporting and accountability for the use of funds (Fitri, 2014). Related research states that the effect of the Educational Operational Grant program on the breakdown of household expenditure in education shows that all items increase, while the amount varies, only tuition fees and special courses are not statistically significant (Fatah, 
2016), and there are some obstacles in managing BOS funds, namely supervision, resources, communication and bureaucratic structure. These four things are very important in managing BOS funds so that the implementation is in accordance with existing regulations (Pontoh et al., 2017).

This study aims to analyze the management of Educational Operational Grant funds and their influence on the development of the Central Jakarta 30 Public High School ", because Central Jakarta Public High School 30 is a transparent school in managing the use of funds provided by the government, that every quarter of the school budget reports the use of Educational Operational Grant funds on display in the school wall magazine.

\section{Method}

The research methods used in this study are descriptive qualitative research method by explaining the condition of school financial management and finding information related to the accountability of aid using management functions starting from planning, organizing, implementing and monitoring, and analysis of fund financing The BOP uses percentage changes in the first, second and third quarters of 2017. Data collection techniques used in this study were interviews, observations, and documents relating to the accountability of education operational assistance funds. While the technique of checking the validity of the data uses triangulation of data sources, methods, investigators, and theories by: asking various questions to informants (the principal, the vice principal of the education affairs and curriculum, the head of school administration), checking various data sources, and utilizing various methods so checking the validity of the data can be done.

\section{Results and Discussion}

\subsection{Results}

After interviewing the head of school administration and the vice principal of the education affairs and curriculum, it was found that after the EOG fund intended for the school development that is quarterly reported was distributed to each fund expenditure post, there was some fund left as. Recapitulation of the Use of Education Operational Grant presented in Tabel 1 and 2.

Tabel 1. Recapitulation of the Use of Education Operational Grant from January to September 2017 (Quarter: I, II, dan III) in the 2017 Fiscal

\begin{tabular}{|c|c|c|c|c|c|c|c|}
\hline \multirow{2}{*}{ No } & \multirow{2}{*}{\multicolumn{2}{|c|}{ Code Number }} & \multirow{3}{*}{$\begin{array}{c}\text { Receipt } \\
4\end{array}$} & \multicolumn{3}{|c|}{ Expenditures } & \multirow{2}{*}{$\begin{array}{c}\text { Returm To } \\
\text { Local } \\
\text { Treasury }\end{array}$} \\
\hline & & & & Quarter I & Quarter li & Quarter lii & \\
\hline 1 & 2 & 3 & & 5 & 6 & 7 & \\
\hline 1 & 5.2 .2 .01 .01 & Stationary & 166.533 .831 & 61.096 .536 & 50.500 .000 & 52.061 .213 & 2.876 .082 \\
\hline 2 & 5.2 .2 .01 .03 & Electricity Tools & 20.676 .373 & 11.092 .400 & 7.816 .600 & 1.706 .100 & 61.273 \\
\hline 3 & 5.2.2.01.05 & Cleaning Tools & 23.548 .187 & 11.369 .050 & 9.115 .550 & 2.951 .300 & 112.287 \\
\hline 4 & 5.2.2.01.10 & Lab Tools & 56.650 .647 & 28.828 .470 & 25.481 .500 & - & 2.340 .677 \\
\hline 5 & 5.2.2.01.11 & Household Appliance & 25.609 .550 & 9.665 .150 & 10.200 .000 & 5.537 .400 & 207.000 \\
\hline 6 & 5.2.2.01.18 & Properties Materials & 57.142 .334 & 19.005 .780 & 9.214 .600 & 24.490 .600 & 4.431 .354 \\
\hline 7 & 5.2.2.03.01 & Telephone & 20.397 .960 & 5.367 .765 & 6.432 .025 & 4.814 .431 & 3.783 .739 \\
\hline 8 & 5.2.2.03.02 & Water & 4.54 .050 & 400.166 & 253.012 & 188.587 & 3.212 .285 \\
\hline 9 & 5.2.2.03.03 & Electricity & 267.059 .030 & 63.463 .650 & 67.790 .670 & 66.661 .560 & 69.143 .150 \\
\hline 10 & 5.2.2.03.06 & $\begin{array}{l}\text { Wires/Fax/Internet/ } \\
\text { Post }\end{array}$ & 54.433 .500 & 16.518 .000 & 16.518 .000 & 16.518 .000 & 4.879 .500 \\
\hline 11 & $\begin{array}{l}5.2 .2 .06 .01 \\
001\end{array}$ & Printing & 36.811 .625 & 10.234 .283 & 11.330 .000 & 15.092 .000 & 155.342 \\
\hline 12 & 5.2.2.11.01 & $\begin{array}{l}\text { Foods And Beverage } \\
\text { For Daily Staffs }\end{array}$ & 16.649 .600 & 3.960 .000 & 3.820 .000 & 5.061 .000 & 3.808 .600 \\
\hline 13 & 5.2.2.11.02 & $\begin{array}{l}\text { Foods And Beverage } \\
\text { For Meetings }\end{array}$ & 87.124 .700 & 40.365 .000 & 10.660 .000 & 30.930 .000 & 5.169 .700 \\
\hline
\end{tabular}




\begin{tabular}{|c|c|c|c|c|c|c|c|}
\hline \multirow{2}{*}{ No } & \multirow{2}{*}{\multicolumn{2}{|c|}{ Code Number }} & \multirow{3}{*}{$\begin{array}{c}\text { Receipt } \\
4\end{array}$} & \multicolumn{3}{|c|}{ Expenditures } & \multirow{3}{*}{$\begin{array}{c}\begin{array}{c}\text { Returm To } \\
\text { Local } \\
\text { Treasury }\end{array} \\
8 \\
\end{array}$} \\
\hline & & & & Quarter I & Quarter li & Quarter lii & \\
\hline 1 & 2 & 3 & & 5 & 6 & 7 & \\
\hline 14 & $\begin{array}{l}5.2 .2 .20 .22 . \\
009\end{array}$ & $\begin{array}{l}\text { Maintenance Of Tools } \\
\text { And Properties } \\
\text { Materials }\end{array}$ & 24.332 .880 & 11.332 .000 & 7.344 .000 & - & 5.656 .880 \\
\hline 15 & $\begin{array}{l}5.2 .2 .20 .26 . \\
009\end{array}$ & $\begin{array}{l}\text { Maintenance For } \\
\text { Educational Facility }\end{array}$ & 833.232 .883 & $\begin{array}{c}232.486 .19 \\
3\end{array}$ & $\begin{array}{c}240.788 .91 \\
7\end{array}$ & $\begin{array}{c}345.326 .80 \\
0\end{array}$ & 14.630 .973 \\
\hline 16 & 5.2.2.27.01 & $\begin{array}{l}\text { Honor For } \\
\text { Instructors/Esourceful } \\
\text { Persons }\end{array}$ & 80.525 .000 & 39.200 .000 & 10.600 .000 & 23.800 .000 & 6.925 .000 \\
\hline & & DTAL & 774.782 .150 & $\begin{array}{c}564.384 .44 \\
3\end{array}$ & $\begin{array}{c}487.864 .87 \\
4\end{array}$ & $\begin{array}{c}595.138 .99 \\
1\end{array}$ & $\begin{array}{c}127.393 .84 \\
2\end{array}$ \\
\hline
\end{tabular}

Source: State Senior High School 30, Central Jakarta

Table 2. Value of the Recapitulation of the Use of Fund Based on the School Program: January to September 2017 (Quarter I, II, dan III) in the 2017 Fiscal Year

\begin{tabular}{|c|c|c|c|c|c|c|}
\hline \multirow{2}{*}{ No } & \multirow{2}{*}{ Code } & \multirow{2}{*}{ Description } & \multirow{2}{*}{ Amount } & \multicolumn{3}{|c|}{ Quarter (\%) } \\
\hline & & & & I & II & III \\
\hline 1 & 2 & 3 & 4 & 5 & 6 & 7 \\
\hline I & 1 & $\begin{array}{l}\text { Development of } \\
\text { Graduate Competence }\end{array}$ & - & - & - & - \\
\hline II & 2 & $\begin{array}{l}\text { Development of } \\
\text { Contents Standard }\end{array}$ & $134,505,000$ & $\begin{array}{l}33,630,000 \\
(25,003 \%)\end{array}$ & $\begin{array}{c}100,875,000 \\
(74,997 \%)\end{array}$ & $\begin{array}{c}0 \\
(0,00 \%)\end{array}$ \\
\hline III & 3 & $\begin{array}{l}\text { Development of } \\
\text { Process Standard }\end{array}$ & $70,128,880$ & $\begin{array}{l}53,980,000 \\
(76.973 \%)\end{array}$ & $\begin{array}{c}0 \\
(0,00 \%)\end{array}$ & $\begin{array}{l}16,148,880 \\
(29.916 \%)\end{array}$ \\
\hline IV & 4 & $\begin{array}{l}\text { Development of } \\
\text { Educators and } \\
\text { Educational Staffs }\end{array}$ & $13,960,000$ & $\begin{array}{l}13,960,000 \\
(100.000 \%)\end{array}$ & $\begin{array}{c}0 \\
(0,00 \%)\end{array}$ & $\begin{array}{c}0 \\
(0,00 \%)\end{array}$ \\
\hline $\mathbf{v}$ & 5 & $\begin{array}{l}\text { Development of School } \\
\text { Infrastructure and } \\
\text { Facility }\end{array}$ & $269,028,464$ & $\begin{array}{l}85,571,054 \\
(31.807 \%)\end{array}$ & $\begin{array}{c}136,768,310 \\
(50.838 \%)\end{array}$ & $\begin{array}{l}46,689,100 \\
(54.562 \%)\end{array}$ \\
\hline VI & 6 & $\begin{array}{l}\text { Development of } \\
\text { Management Standard }\end{array}$ & $38,554,400$ & $\begin{array}{l}110,000 \\
(0.285 \%)\end{array}$ & $\begin{array}{l}18,381,000 \\
(47.675 \%)\end{array}$ & $\begin{array}{c}20,063,400 \\
(52.039 \%)\end{array}$ \\
\hline VII & 7 & $\begin{array}{l}\text { Development of } \\
\text { Financial Standard }\end{array}$ & $265,599,150$ & $\begin{array}{c}0 \\
(0,00 \%)\end{array}$ & $\begin{array}{c}148,492,650 \\
(55,909 \%)\end{array}$ & $\begin{array}{c}117,106,500 \\
(44,091)\end{array}$ \\
\hline VIII & 8 & $\begin{array}{l}\text { Development of } \\
\text { Evaluation System } \\
\text { Implementation }\end{array}$ & 0 & $\begin{array}{c}0 \\
(0,00 \%)\end{array}$ & $\begin{array}{c}0 \\
(0,00 \%)\end{array}$ & $\begin{array}{c}0 \\
(0,00 \%)\end{array}$ \\
\hline & & TOTAL & $791,775,894$ & $\begin{array}{c}187,251,054 \\
(23,650 \%) \\
\end{array}$ & $\begin{array}{c}404,516,960 \\
(51,090 \%)\end{array}$ & $\begin{array}{c}200,007,880 \\
(25.261 \%)\end{array}$ \\
\hline
\end{tabular}

Based on the grouping of sixty expenditures of the EOG fund as presented in Table 2 above, the expenditures may be grouped into 8 (eight) descriptions in the Development in the Field of Education. The greatest amount of fund was allocated for the development of school facilities and infrastructures namely Rp. 269,028,464 (33,98\%) and for the lowest amount was for the development of educators and educational staffs $(1,76 \%)$

Fund for the development of facilities and infrastructures was divided into 3 (three) quarters of which the greatest amount was for Quarter III. The fund for the development of educators and the educational staffs was used in the quarter I.

\subsection{Discussion}

\section{a. Functions of Management}

Planning

The preparation and the planning of the use of the EOG fund based on the quarterly school program was made through three stages including : a) grouping the use of fund based on the level of the school need and on the educational national standard (INDONESIA, 2005); b) the determination of the focus and target in line with the agenda and problems faced by 
the school ; c) the determination in the school development ; and d) the determination of the parties that would be involved in the use of the EOG fund, the parties involved in the high school operational team to achieve high performance involving human resources in a team become the main management strategy in aligning the vision and strategy (Gibbs \& Poisat, 2019).

\section{Organization}

Organizations such as schools in involving human resources require employees to create added value that contributes to school activities, and success in managing an organization has an impact on competent and high performance human resources, (Mercer, 2010) which includes the determination of the tasks and roles for the involved parties (the principal, the vice principal, the teachers, the staffs and the students), the choice of the instructors or resourful persons for the school extracuricullar activities, the establishment of work teams grouped on the basis of the students' learning capability such as activities for strengthening the materials of the school and national final examinations.

The principal as the top leader at school gave the direction for the school management in terms of the attainment of the aim. It is in line with Bush's opinion that achievement of organizational goals is managed by a good management system that is the principal as the manager and the stakeholders.(Bush, 2007) Related research which states that, school development that leads to resource development refers to regulations set by the government for uniformity (Tamir, 2019).

State Senior High School 30 Central Jakarta also made some organization in the form of cooperation with other schools in other regions of the Capital Special Region of Jakarta. This cooperation is aimed at encouraging some school changes and development in order to improve the quality of education and the school with the best performance and an effective school system, (Dinham, 2013) update the knowledge structure in real time, expand horizons and teaching ideas, keep up with cutting-edge information, and improve teaching capabilities (Huang \& Liu, 2020).

\section{Implementation}

State Senior High School 30 Central Jakarta is a school under the education office of the government agency named "Non profit Organization", meaning that in the accountability of the EOG fund provided by the government, school trust and reputation are vital. To realize the vision and the missions of this school, in implementing the school management activities,

It is necessary to have an effective management strategy to manage the resources, the environment and the determining culture. Implementation of educational strategies refers to educational values and focus on instrumental goals related to the conceptual framework into empirical concepts (Scharf et al., 2019) to achieve mission of the school. Mission is an explanation of the vision, stimulating the achievement of vision, and the process of valuing organizations. It is found that to reach its missions, Senior High School 50 Central Jakarta consisted of three functions" the first function is to control the school mission in the use of the fund intended to avoid any misuse in accordance with the fields; the second function is to motivate the staffs and the parents, and the school committee; and the third function is to help the process of evaluation of the school organization conducted by the education agency.

In the analysis of the EOG fund management, the principal the one responsible for the education funding budget management at this implementation function referred to the goal of the financial management namely improving effectiveness and efficiency in the school financial use, and the school financial accountability and transparency and also reducing any school budget misuse because budgeting is the creation of an activity plan which is stated in the financial measure and budgeting plays an important role in planning, controlling and decision making. Budget is also intended to improve some coordination and communication in implementing any school activities, and effective school financial accountability is carried out by managing finances appropriately through the correct methods (Tesfaye, 2018).

The process of the coordination in the implementation of the school fund was conducted by concerned parties: the provincial government makes various policies and strategies which 
are described in the form of programs and activities which are implemented under coordination the local government through the education agency and also principals (Rismita, 2018).

\section{Supervision}

This function covers the utilization of the evaluation results of the accountability in the use of the EOG fund as the planning reference. Therefore, a school should always make an institutional evaluation. Any data and information obtained in the evaluation were processed and analyzed using the goal setting theory and the EOG funding analysis.

Goal setting theory explains how a school reaches a goal related to a vision and missions. Therefore, a goal will determine the results attained by various activities made. The vision and missions of the State Senior High School 30 Central Jakarta are related to the goal of motivating, coordinating and leaning the behaviors of the people in the school. The goal is intended to give some effects of the standard and optimal results in the evaluation of the school functions. It is in line with the opinion presented by Locke and Latham that the principles of a goal consist of the followings: (a): Goals are motivational, (b) People work harder for more challenging goals, (c) Variations in ability impact goal-related performance gains, (d) Self-efficacy and related belief systems influence goal achievement, (e) Feedback interacts with goal success, (f) Goal commitment moderates the impact of goal setting, (g) Goals direct attention and affect activity selection (Locke \& Latham, 2013).

The standard and results that had been reached by State Senior High School 30 Central Jakarta, in terms of the management of the EOG fund, are said to have been in lie with Locke and Latham's opinion. The achievements based on the competency of students' assignments themselves, themselves, and others who are focused on positive success that had been achieved (Elliot et al., 2015), in the Kappes research also explained the positive contribution of academic results by using students implicit intelligence (Kappes et al., 2011), in general consensus the educational achievement of students depends on the personal characteristics of students and the school, (Thieme et al., 2016) were as follows: the students of State Senior High School 30 Central Jakarta had graduated $100 \%$ and had an access to enroll in state universities without tests, this school served as a host for the national science Olympic (March, 2018), it was one of the referral school in terms of culture and arts (2018), it had been the first winner of Pencak Silat in the Provincial Sports Week (Porprov) 1 of Capital Special Region of Jakarta (2017), and it had an achievement in Karawitan (Traditional Javanese Music Performance), Runner II at the provincial level (October 2016)

The achievement above showed that the vision and missions of the school succeeded in reaching the goals, as stated by Locke \& Latham that the importance of goal setting because it is related to social and cognitive theories. The two theories differ in emphasis and scope. The focus of goal setting theory is on the core properties of an effective goal (Locke \& Latham, 2002).

Moreover Locke \& Latham stated that, the purpose of setting goals is to determine effectiveness in managing the organization together (Locke \& Latham, 2006), as well as setting the best personal goals associated with the development of achieving students' academic cycles (Martin \& Elliot, 2016).

Dealing with the attainment of the goal above, referring to Locke's model, the determination of a goal has four mechanisms to motivate individuals to attain a good performance. First, the determination of a goal may lead an individual's attention to focus the achievement of the goal. Second, a goal may help organize efforts made by individuals to reach the goal. Third, the existence of a goal may improve individuals' perseverance to reach the goal. Fourth, a goal help individuals determine strategies and make actions as planned (Kinichi \& Kreitner, 2004). Thus, setting goals regarding fund management is a responsibility that has to do with the education profession (Lowenhaupt et al., 2016).

On the basis of the descriptions above, State Senior High School 10 Central Jakarta allocated the EOG fund in line with the rules and no deviation made, so that this school may be used as a model for other schools since it had not misused the EOG fund.

The effects and benefits of the EOG fund in State Senior High School 30 Central Jakarta were resulted in by the fact that the school had conducted the fund use on the basis of the 
school programs referring to the education national standard which is in line with the principles of Locke and Latham's goal setting theory. The school had achieved its vision namely" Superiority in academic or non academic achievement". And face increased accountability demands from the government (Kretchmar \& Zeichner, 2016). The results of this present research are in line with Lunenburg's that: achievement, both individually and in groups, has the same goals for the school (Lunenburg, 2011).

\section{b. Financial Analysis of EOG Fund for Quarters I, II, and III}

The financial analysis of the EOG fund is intended to make an estimation of the fund counted on the basis of the fund percentage per quarter. Therefore, the analysis is made by using the number of fund based on the groups of use of the school program fund.

The calculation of the financial analysis of the EOG fund use is based on the data obtained in this present research from January to September 2017 by comparing the fund in Quarter I for the basic year (100\%) and Quarters II and III as the current year. The results of the analysis is presented in Table 3.

Table 3. The Analysis of EOG Fund from January to September 2017 (Quarters: I, II, and III) in 2017 Fiscal Year

\begin{tabular}{|c|c|c|c|c|c|c|}
\hline \multirow{2}{*}{ No. } & \multirow{2}{*}{ Code } & \multicolumn{3}{|c|}{ Financial analysis (\%) } & \multirow{2}{*}{ Fund Use (\%) } & \multirow{2}{*}{$\begin{array}{l}\text { Fund Use } \\
\text { Left (\%) }\end{array}$} \\
\hline & & Quarter I & Quarter II & Quarter III & & \\
\hline 1. & Stationary & 100 & 82,656 & 85,211 & 98,273 & 1,727 \\
\hline 2. & Electricity tools & 100 & 70,468 & 15,381 & 99,704 & 0,296 \\
\hline 3. & Cleaning tools & 100 & 80,179 & 25,959 & 99,523 & 0,477 \\
\hline 4. & Lab tools & 100 & 88,390 & 0,000 & 95,868 & 4,132 \\
\hline 5. & Household appliance & 100 & 105,534 & 57,292 & 99,192 & 0,808 \\
\hline 6. & Properties materials & 100 & 48,483 & 128,859 & 92,245 & 7,755 \\
\hline 7. & Telephone & 100 & 119,827 & 89,692 & 81,450 & 18,55 \\
\hline 8. & Water & 100 & 63,227 & 47,127 & 20,764 & 79,236 \\
\hline 9. & Electricity & 100 & 106,818 & 105,039 & 74,109 & 25,891 \\
\hline 10 & Wires/fax/internet/post & 100 & 100,000 & 100,000 & 91,036 & 8,964 \\
\hline 11 & Printing & 100 & 110,706 & 147,465 & 99,578 & 0,422 \\
\hline 12 & $\begin{array}{l}\text { Foods and benerage for daily } \\
\text { staffs }\end{array}$ & 100 & 96,465 & 127,803 & 77,125 & 22,875 \\
\hline 13 & $\begin{array}{l}\text { Foods and beverage for } \\
\text { meetings }\end{array}$ & 100 & 26,409 & 76,626 & 94,066 & 5,934 \\
\hline 14 & $\begin{array}{l}\text { Maintenance of tools and } \\
\text { properties materials }\end{array}$ & 100 & 64,808 & 0,000 & 76,752 & 23,248 \\
\hline 15 & $\begin{array}{l}\text { Maitenance of educational } \\
\text { facility }\end{array}$ & 100 & 103,571 & 148,536 & 98,244 & 1,756 \\
\hline \multirow[t]{2}{*}{16} & $\begin{array}{l}\text { Honor } \\
\text { Instructor/resourceful persons }\end{array}$ & 100 & 27,041 & 60,714 & 91,400 & 8,600 \\
\hline & TOTAL & 100 & 86,442 & 105,449 & 92,822 & 7,178 \\
\hline
\end{tabular}

The results of the financial analysis of the EOG fund presented in Table 3 above showed that total use of the EOG fund in the State Senior High School 30 Central Jakarta was for buying 16 items. From the analysis, it is shown that the percentage of the expenditure in Quarter II decreased for $13.6 \%$ compared with that of Quarter I (the use of the EOG fund in quarter I $=100 \%$, while in Quarter II $=86.422 \%$ ) and in Quarter III the percentage increased for $5.45 \%$ compared with Quarter I (the use of the EOG fund in Quarter II $=86.422 \%$, while Quarter III $=105.449 \%$ ). The total use of the EOG fund was $92.822 \%$ and the rest of the EOG fund $(7.178 \%)$ was returned to the Local Treasury.

The percentage showed that the EOG fund in the State Senior High School 30 Central Jakarta is used optimally to operate the education in the school and fulfills all expenditures of the school in order to provide the standard of the education services so that the sustainability and the continuance of the availability system of the EOG fund on the basis of the financial analysis may be maintained in the next in the State Senior High School 30 Central Jakarta by holding the transformer position (Zeichner et al., 2014). In research related to school improvement grants, it explains that grants are useful for achieving improvements such as providing assistance to schools in the form of additional financial resources in the hope that schools must experience significant changes in the educational aspect, (Carlson \& Lavertu, 
2018) schools that focus on results and developing school autonomy can improve the quality of education (Van der Sluis et al., 2017).

State Senior High School 30 Central Jakarta could work well since it had an effective fund management system for implementing the education, revealed in a theory that the more effective use of financial resources, the better the school's academic performance. (Othoo et al., 2019) From the analysis of the EOG fund management, this school had managerial functions from planning to supervising. The analysis was made by grouping the fund in line with the educational financing leading to the attainment of the education goal using the goal setting theory since anything dealing with the education financing may influence the development of education and budgeting can present major challenges to school development (Arnold \& Gillenkirch, 2015) and based on these regulations will have an impact on how the education program is expected to function (Kumashiro, 2010).

The descriptions above are in line with Mestry \& Bisschoff's opinion that managing school finances in accordance with the allocation of the use of funds determined based on educational operational grant guidelines is a good action that affects school development (Mestry, 2016).

Based on the results of the analysis discussed above, that the headmaster of the State Senior High School 30 Central Jakarta as an initiative in managing EOG funds by classifying the use of funds based on school programs and education standards has carried out their duties in accordance with the objectives of the school they lead and has been successful in developing schools as measured by educational outcomes and process criteria and other performance criteria, namely: (1) student outcomes, (2) educational services and (3) leadership, management and school self-evaluation development, (Sampaio \& Leite, 2017) and parent and student interest in a school can be seen from the internal and external factors of the school (Bush, 2019). The change in the improvement of school development is often associated with the performance of leadership in achieving school quality in education (Bush, 2008), and the influence of collaborative leadership will contribute to theories of public sector leadership on organizational rules and organizational performance (Hsieh \& Liou, 2016).

\section{Conclusions and Recomendations}

The management of EOG funds at the State Senior High School 30 Central Jakarta is managed by the school principal by using various principals' knowledge and skills as top management effectively by grouping the use of BOP funds in accordance with school programs, and efficiently by using funds optimally. The principal as the person responsible for managing funds plays a role based on the school financial management functions that are clearly implemented and builds a system for monitoring the use of funds based on fund management principles, namely: flexibility, accountability, and transparency in developing schools to achieve the school's vision and mission obtained from the results of performance criteria and the education process is based on a measure of school progress or student achievement that is achieved from the various achievements of the school.

In this study, it is recommended that schools provide a careful and systematic picture of fund management and channeling assistance in accordance with the number of students registered at the school so that no refunds occur with reference to the budget that has occurred in previous years, so that the school achieves performance the best and effective school system.

\section{References}

Arnold, M. C., \& Gillenkirch, R. M. (2015). Using negotiated budgets for planning and performance evaluation: An experimental study. Accounting, Organizations and Society, 43, 1-16. https://doi.org/10.1016/j.aos.2015.02.002

Bruns, B., Filmer, D., \& Patrinos, H. A. (2011). Making Schools Work: New Evidence on Accountability Reforms. The World Bank. https://doi.org/10.1596/978-0-8213-8679-8

Bush, T. (2007). Educational leadership and management: Theory, policy and practice. South African Journal of Education, 27(3), 391-406.

Bush, T. (2008). Leadership and management development. SAGE. 
Bush, T. (2019). School leaders and accountability: Performance or performativity? Educational Management Administration \& Leadership, 47(2), 167-169. https://doi.org/10.1177/1741143218817949

Carlson, D., \& Lavertu, S. (2018). School Improvement Grants in Ohio: Effects on Student Achievement and School Administration. Educational Evaluation and Policy Analysis, 40(3), 287-315. https://doi.org/10.3102/0162373718760218

Dinham, S. (2013). The quality teaching movement in Australia encounters difficult terrain: A personal perspective. Australian Journal of Education, 57(2), 91-106. https://doi.org/10.1177/0004944113485840

Elliot, A., Murayama, K., Kobeisy, A., \& Lichtenfeld, S. (2015). Potential-based achievement goals. British Journal of Educational Psychology, 85(2), 192-206. https://doi.org/10.1111/bjep.12051

Fatah, A. A. (2016). The Impact of Bantuan Operasional Sekolah (BOS) Program: School Operational Assistance to the Household Expenditures in Education: A Case Study of Indonesia. Martin School of Public Policy and Administration University of Kentucky, 29.

Fitri, A. (2014). Pengelolaan dana Bantuan Operasional Sekolah (BOS) SD Negeri Kecamatan Mandiangin Koto Selayan Kota Bukittinggi. Jurnal Bahana Manajemen Pendidikan, 2, 33-39. https://doi.org/10.23036/bmp.v2i1.3753

Gibbs, M., \& Poisat, P. (2019). Educator Engagement: Key to High Performance of School Operational teams in South African Secondary Schools. Africa Education Review, 16(4), 37-52. https://doi.org/10.1080/18146627.2017.1394166

Haynes, N. M., Arafeh, S., \& McDaniels, C. (Eds.). (2015). Educational leadership: Perspectives on preparation and practice. University Press of America.

Howieson, B. (2003). Accounting practice in the new millennium: Is accounting education ready to meet the challenge? The British Accounting Review, 35(2), 69-103. https://doi.org/10.1016/S0890-8389(03)00004-0

Hsieh, J. Y., \& Liou, K. T. (2016). Collaborative Leadership and Organizational Performance: Assessing the Structural Relation in a Public Service Agency. Review of Public Personnel Administration, 27. https://doi.org/10.1177/0734371X15623619

Huang, Z., \& Liu, Y. (2020). Research on Management Accounting Practice: A Network Teaching Model Guided by Practical Simulation. Modern Economy, 11(01), 89-95. https://doi.org/10.4236/me.2020.111009

INDONESIA, P. R. (2005). PERATURAN PEMERINTAH REPUBLIK INDONESIA NOMOR 19 TAHUN 2005 TENTANG STANDAR NASIONAL PENDIDIKAN. http://www.academia.edu/download/42688161/pengumuman_46.pdf

Ishak, N. Mohd., Iskandar, I. P., \& Ramli, R. (2010). Emotional intelligence of Malaysian teachers: A comparative study on teachers in daily and residential schools. Procedia Social and Behavioral Sciences, 9, 604-612. https://doi.org/10.1016/j.sbspro.2010.12.205

Kappes, H. B., Stephens, E. J., \& Oettingen, G. (2011). Implicit theories moderate the relation of positive future fantasies to academic outcomes. Journal of Research in Personality, 45(3), 269-278. https://doi.org/10.1016/j.jrp.2011.02.006

Kretchmar, K., \& Zeichner, K. (2016). Teacher prep 3.0: A vision for teacher education to impact social transformation. Journal of Education for Teaching, 42(4), 417-433. https://doi.org/10.1080/02607476.2016.1215550

Kumashiro, K. K. (2010). Seeing the Bigger Picture: Troubling Movements to End Teacher Education. Journal of Teacher Education, 61(1-2), 56-65. https://doi.org/10.1177/0022487109347318

Lee, K.-G., \& Polachek, S. W. (2018). Do school budgets matter? The effect of budget referenda on student dropout rates. Education Economics, 26(2), 129-144. https://doi.org/10.1080/09645292.2017.1404966

Locke, E. A., \& Latham, G. P. (2002). Building a practically useful theory of goal setting and task motivation: A 35-year odyssey. American Psychologist, 57(9), 705-717. https://doi.org/10.1037//0003-066X.57.9.705 
Locke, E. A., \& Latham, G. P. (2006). New Directions in Goal-Setting Theory. Current Directions in Psychological Science, 15(5), 265-268. https://doi.org/10.1111/j.14678721.2006.00449.x

Locke, E. A., \& Latham, G. P. (2013). New Developments in Goal Setting and Task Performance. Routledge.

Lowenhaupt, R., Spillane, J. P., \& Hallett, T. (2016). Education Policy in Leadership Practice: "Accountability Talk" in Schools. Journal of School Leadership, 26(5), 783-810. https://doi.org/10.1177/105268461602600503

Lunenburg, F. C. (2011). Goal-Setting Theory of Motivation. International Journal Of Management, Business, And Administration, 15, 6.

Manu, B. D., Zhang, H., Oduro, D., Krampah-Nkoom, A., Mensah, I. A., Anaba, O. A., \& Isaac, A. (2019). School Board Efficiency in Financial Management and Human Resource in Public Senior High Schools: An Evidence from Ashanti Region, Ghana. International Journal of Social Science Studies, 8(1), 79. https://doi.org/10.11114/ijsss.v8i1.4556

Martin, A. J., \& Elliot, A. J. (2016). The role of personal best (PB) goal setting in students' academic achievement gains. Learning and Individual Differences, 45, 222-227. https://doi.org/10.1016/j.lindif.2015.12.014

Mercer, J. (2010). Human Resource Management in Education: Contexts, Themes and Impact (1st ed.). Routledge. https://doi.org/10.4324/9780203850817

Mestry, R. (2016). The management of user fees and other fundraising initiatives in selfmanaging public schools. South African Journal of Education, 36(2), 1-11. https://doi.org/10.15700/saje.v36n2a1246

Mohamad, M., \& Jais, J. (2016). Emotional Intelligence and Job Performance: A Study among Malaysian Teachers. Procedia Economics and Finance, 35, 674-682. https://doi.org/10.1016/S2212-5671(16)00083-6

Othoo, H. A., A. Olel, M., \& Gogo, J. (2019). Finanacial Resources as Determinants of Academic Performance in Public Secondary Schools in Kuria East and Kuria West SubCounties, Kenya. American Journal of Social Sciences and Humanities, 4(2), 392-406. https://doi.org/10.20448/801.42.392.406

Pontoh, J., Ilat, V., \& Manossoh, H. (2017). Analisis Pengelolaan Dana Bantuan Operasional Sekolah (BOS) pada Satuan Pendidikan Dasar di Kota Kotamobagu. Jurnal Riset Akuntansi dan Auditing "GOODWILL," 8(2). https://doi.org/10.35800/jjs.v8i2.18266

Rismita, -. (2018, February 4). The Implementation of Tuition-Free School Policy Using Stake's Countenance Evaluation Model. First Indonesian Communication Forum of Teacher Training and Education Faculty Leaders International Conference on Education 2017 (ICE 2017). https://doi.org/10.2991/ice-17.2018.110

Sampaio, M., \& Leite, C. (2017). From curricular justice to educational improvement: What is the role of schools' self-evaluation? Improving Schools, 20(1), 62-75. https://doi.org/10.1177/1365480216688553

Scharf, J., Hadjar, A., \& Grecu, A. (2019). Applying social production function theory to benefits of schooling: The concept of values of education. British Journal of Sociology of Education, 40(7), 847-867. https://doi.org/10.1080/01425692.2019.1604207

Tamir, E. (2019). High school managements resources allocation in an era of reforms. International Journal of Educational Management Vol. 33 No. 5, 2019 Pp. 828-847 (C) Emerald Publishing Limited 0951-354X DOI 10.1108/IJEM-08-2017-0204, Vol.33 No. 5, 2019, 20.

Tesfaye, G. (2018). Addis Ababa University College of Education and Behavioral Studies Department of Educational Planning and Management. 109.

Thieme, C., Prior, D., Tortosa-Ausina, E., \& Gempp, R. (2016). Value added, educational accountability approaches and their effects on schools' rankings: Evidence from Chile. European Journal of Operational Research, 253(2), 456-471. https://doi.org/10.1016/j.ejor.2016.01.023

Uljens, M., \& Ylimaki, R. M. (Eds.). (2017). Bridging Educational Leadership, Curriculum Theory and Didaktik (Vol. 5). Springer International Publishing. https://doi.org/10.1007/978-3-319-58650-2 
Van der Sluis, M. E., Reezigt, G. J., \& Borghans, L. (2017). Implementing New Public Management in Educational Policy. Educational Policy, 31(3), 303-329. https://doi.org/10.1177/0895904815598393

Weltbank (Ed.). (2003). Sustainable development in a dynamic world: Transforming institutions, growth, and quality of life. Oxford Univ. Press.

World Bank. (2004). World Development Report 2005: A Better Investment Climate for Everyone. The World Bank. https://doi.org/10.1596/0-8213-5682-8

Zeichner, K., Payne, K. A., \& Brayko, K. (2014). Democratizing Teacher Education. Journal of Teacher Education, 14. https://doi.org/10.1177/0022487114560908 